\section{In vivo Assay for Melanocyte Lightening Substances}

Introduction. Destruction of the frog hypothalamus causes a maximum dispersal of melanin granules in the dermal and epidermal melanocytes with resulting darkening of the skin ${ }^{1}$. This is probably due to an increased release of melanocyte stimulating hormone (MSH) from the pituitary as a result of removal of the hypothalamic inhibitory influence ${ }^{2}$.

The present study utilizes these hypothalamic lesioned frogs for the assay of substances causing aggregation of melanin granules (melanocyte lightening). The use of melatonin, the most potent lightening compound known, is suggested as the standard.

Methods. Adult male frogs (Rana pipiens), weighing 30-50 g, were anesthetized with ether. After the mucosa of the mouth was incised, the parasphenoid bone between the regions of the pituitary and optic chiasma was drilled with a dental burr until only a thin lamina of cartilage covered the hypothalamic area. This cartilagenous flap was excised and the hypothalamic lobes removed by suction.

Solutions were injected into the dorsal lymph sac of frogs lesioned at least 3 days before assay ${ }^{3}$. Only frogs with a melanocyte index (MI) of 5.0 on the scale of $1.0-5.0^{3,4}$ were utilized. The convenient $1 \mathrm{~h}$ response approximated the maximum MI decrease and was used in the assay.

The compounds tested were dissolved in absolute ethanol, $0.1 \mathrm{~N} \mathrm{NaOH}, 0.01 \mathrm{~N} \mathrm{HCl}-0.9 \%$ aqueous $\mathrm{NaCl}$, or in Number 100 Sterile Vehicle (Upjohn). All subsequent dilutions were made with the acid saline.

Results and discussion. The substances assayed for their ability to cause melanocyte lightening in frogs previously darkened by removal of the hypothalamus are shown in the Table. Melatonin was clearly the most potent lightening agent tested. The failure of large doses of many of the other compounds to cause melanocyte lightening is indicative of the specificity of the assay.

Whereas $4.0 \mathrm{mg}$ of $N$-acetyl serotonin did not lighten the frogs, only $0.4 \mathrm{mg}$ of 5-methoxytryptamine did reduce the MI to 4.0. This indicates that the O-methyl group is more important for the lightening capacity of melatonin than the $N$-acetyl group, although both are necessary for maximum activity.

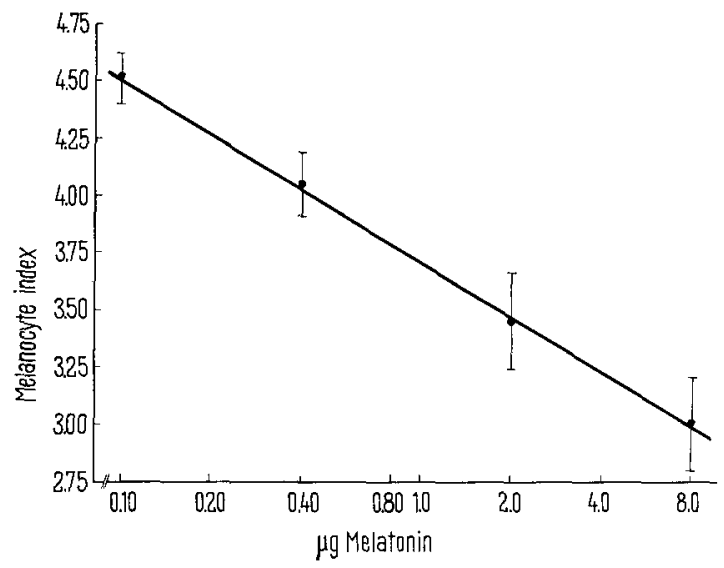

Regression line of melanocyte index responses to melatonin in 160 frogs, with $95 \%$ confidence limits for each mean response.
The darkened frogs can be reutilized on successive days. After repeated handling, however, some frogs may temporarily lighten.

The MI responses were found to be a linear function of the log dose of the compounds tested. The Figure shows the regression line for melatonin calculated by the method of least squares. The $95 \%$ confidence limits are represented for each mean response.

Melatonin appears to be a suitable standard for the assay of melanocyte lightening substances. The amount of melatonin necessary to produce a decrease in the MI to 4.0 might be defined as 'unit' activity. In such a case, $0.45 \mu \mathrm{g}$ of melatonin would produce a response equivalent to 1 unit ${ }^{5}$.

Melanocyte lightening activity of various substances in the lesioned frog

\begin{tabular}{ll}
\hline & $\begin{array}{l}\mu g \text { of substance } \\
\text { reducing MI } \\
\text { to } 4.0\end{array}$ \\
Melatonin (5-methoxy- $N$-acetyltryptamine) & 0.45 \\
5-Methoxytryptamine & 400 \\
Epinephrine & 20 \\
Norepinephrine & 20 \\
\hline & $\mu$ failing to re- \\
& duce MI ${ }^{\text {a }}$ to 4.0 \\
$N$-Acetyl serotonin & 4000 \\
Serotonin creatinine sulfate & 4000 \\
Serotonin hydrogen oxalate & 4000 \\
Tryptamine & 4000 \\
$N, N$-Dimethyltryptamine & 4000 \\
Acetylcholine & 4000 \\
Histamine & 4000 \\
Hydrocortisone & 4000 \\
Dexamethasone & 4000 \\
Conjugated estrogens & 4000 \\
L-Triiodothyronine & 2000 \\
L-Thyroxine & 1000 \\
\hline
\end{tabular}

${ }^{\mathrm{a}} \mathrm{MI}=$ melanocyte index.

Résumé. L'emploi de grenouilles dont la pigmentation est noircie par l'ablation de la région hypothalamique est presentée comme une méthode d'essai des substances éclaircissant les mélanocytes. Bien que la présence des deux groupes $\mathrm{O}$-methyl et $N$-acetyl de la mélatonine soit nécessaire pour un effet éclaircissant maximum, il semble que le groupe O-methyl soit le plus important. La mélatonine est proposée comme standard.

\section{A. J. Kastin and A. V. Schally}

Endocrine and Polypeptide Laboratories, Veterans Administration Hospital, and Department of Medicine, Tulane University School of Medicine, New Orleans (Louisiana USA), December 29, 1965.

I W. Etrin, Gen. comp. Endocr., Suppl. 1, 148 (1962).

2 A. J. Kastin and G. T. Ross, Endocrinology 77, 45 (1965).

3 A. J. Kastin and G. T. Ross, Experientia 20, 461 (1964).

4 I. Hogben and C. Gordon, J. exp. Biol. 7, 286 (1930).

5 The authors thank Dr. G. T. Ross and Dr. R. WuRTMan for valuable suggestions, Dr. S. P. H. MANDEL for statistical aid, and Miss LynN WILKINSON for technical assistance. This study was supported in part by NIH grant AM 07467-03. 